\title{
Traumatic Injury and Multiple Sclerosis: A Systematic Review and Meta-Analysis
}

\author{
Sharon A. Warren, Susan Armijo Olivo, Jorge Fuentes Contreras, \\ Karen V.L. Turpin, Douglas P. Gross, Linda J. Carroll, Kenneth G. Warren
}

\begin{abstract}
A systematic review/meta-analysis of literature addressing a possible association between traumatic injury and onset of multiple sclerosis was conducted. Medline, Embase, Cochrane DSR, Ovid HealthStar, CINAHL, ISI Web of Science and Scopus were searched for analytical studies from 1950 to 2011. Two investigators independently reviewed articles for inclusion, assessing their quality using the Newcastle-Ottawa Scale. Of the 13 case-control studies included, 8 were moderate quality and 5 low; of the 3 cohort studies 2 were high and 1 moderate. Meta-analysis including moderate and low quality case-control studies produced a modest but significant odds ratio: 1.41 (95\% confidence interval: $1.03,1.93)$. However, when low quality studies were excluded, the resulting odds ratio was non-significant. Cohort studies produced a non-significant standardized incidence ratio of 1.00 (95\% confidence interval: 0.86 , 1.16). These findings support the conclusion that there is no association between traumatic injury and multiple sclerosis onset; more high quality cohort studies would help to confirm this observation.
\end{abstract}

RÉSUMÉ: Traumatisme et sclérose en plaques : revue systématique de la littérature et méta-analyse. Nous avons effectué une revue systématique de la littérature et une méta-analyse sur une association possible entre un traumatisme et le début de la sclérose en plaques (SP). Nous avons recherché les études analytiques publiées de 1950 à 2011 dans Medline, Embase, Cochrane DSR, Ovid HealthStar, CINAHL, ISI Web of Science et Scopus. Deux chercheurs ont révisé de façon indépendante les articles et évalué leur qualité au moyen de l'échelle Newcastle-Ottawa. Parmi les 13 études cas-témoin que nous avons retenues, 8 étaient de qualité moyenne et 5 de qualité médiocre, alors que parmi les 3 études de cohorte, 2 étaient de haute qualité et 1 de qualité moyenne. Le rapport de cotes obtenu de la méta-analyse qui incluait des études cas-témoin de qualité moyenne et médiocre était modeste mais significatif : 1,41 (intervalle de confiance à 95\%:1,03 à 1,93). Cependant, quand nous avons exclu de l'analyse les études de qualité médiocre, le rapport de cotes n'était pas significatif. Le taux d'incidence standardisé pour les études de cohorte était de 1,00 (IC à 95\%: 0,86 à 1,16 ), donc non significatif. Ces observations indiquent qu'il n'existe pas d'association entre un traumatisme et le début de la sclérose en plaques. D'autres études de cohorte de haute qualité aideraient à confirmer cette observation.

Can J Neurol Sci. 2013; 40: 168-176

Multiple sclerosis (MS) represents one of the leading causes of neurological disability in young adults. ${ }^{1}$ Despite decades of epidemiological, genetic, clinical and laboratory studies, the cause of MS is not fully understood. Based on the disease's diverse clinical and pathological manifestations, it is believed that the cause of MS is multi-factorial. The predominant current theory is that both environmental and genetic factors are involved in its etiology. ${ }^{2}$ Categories of environmental variables such as: climate and solar radiation, infections and living conditions, diet and trace elements have been studied extensively. Infection with Epstein-Barr virus, vitamin D deficiency and cigarette smoking are the most common factors currently being investigated; however, there is no conclusive evidence that these three, or any other environmental risk factors, have more than a small effect on the development of MS. ${ }^{3}$

The possibility that traumatic injury might be a risk factor for MS dates from the earliest descriptions of the illness by Charcot. ${ }^{4}$ One frequently advanced, biologically plausible mechanism is that traumatic injury might cause a temporary breakdown in the blood brain barrier, allowing T-lymphocyte cells to enter the central nervous system where they contribute to the development of MS plaques. ${ }^{5}$ Numerous observational studies have examined whether there is an association between traumatic injury and the development of MS, with conflicting results. The Therapeutics and Technology Assessment Subcommittee of the American Academy of Neurology (AAN) published a best evidence synthesis in $1999^{6}$ which concluded that research does not substantiate such an association. However, while this synthesis classified each article according to level of evidence, it did not assign critical appraisal scores nor use metaanalytic techniques to quantify the association between

From the Faculty of Rehabilitation Medicine (SAW), Faculty of Medicine and Dentistry (SAO, KGW), Rehabilitation Research Centre (JFC), Department of Public Health Sciences (KVLT, LJC), Department of Physical Therapy (DPG), Alberta Centre for Injury Control and Reasearch (LJC), University of Alberta, Edmonton, Alberta; Institute for Work and Health (LJC) Toronto, Ontario, Canada; Department of Physical Therapy (JFC), Catholic University of Maule, Talca, Chile.

Received June 26, 2012. Final Revisions Submitted September 19, 2012. Correspondence to: Sharon Warren, Rehabilitation Research Centre, University of Alberta, Edmonton, Alberta, Canada. Email: sharon.warren@ualberta.ca. 
traumatic injury and MS. Clarification of the role of traumatic injury in MS is important not only on pathogenic but also on medical-legal grounds since persons with MS continue to seek compensation for injuries which they feel may have caused their disease, adding to debate on this topic. ${ }^{7-10}$ Critical appraisal of studies using a widely available and structured critical appraisal form and assigning scores for quality would provide additional credibility to conclusions about an association; quantification through producing a combined effect size would allow an assessment of the importance of traumatic injury as a risk factor. We conducted an updated systematic review including articles not covered by the AAN report, critically appraised identified articles using a structured appraisal form and employed metaanalysis techniques to address the probability of an association between traumatic injury and MS onset.

\section{Methods}

Reporting of this systematic review and meta-analysis follows the guidelines established by the Meta-Analysis of Observational Studies in Epidemiology group, ${ }^{11}$ since these are more appropriate to a review of risk factors based on casecontrol and cohort studies than guidelines designed for experimental studies such as randomized controlled trials (RCTs). Randomized controlled trials cannot be used to examine risk factors for a disease on ethical grounds. Consequently casecontrol and cohort studies, despite their greater susceptibility to bias, must be relied on to assess risk.

\section{Criteria for inclusion of studies}

Only case-control and cohort studies were selected for the systematic review; descriptive studies with no comparison group based on either exposure or outcome were ruled out. Studies must have reported a measure of association between traumatic injury and MS onset, such as an odds ratio (OR) or standardized incidence ratio (SIR) or provided original data on the occurrence of traumatic injury by disease status from which a measure of effect could be calculated. Studies were included if they involved humans with a diagnosis of MS without restriction by age, gender, geographic region, or race/ethnicity of study participants. The exposure of interest was a traumatic injury, as defined by medical sub-heading (MeSH) terms used in Medline and Pubmed databases: "Any physical damage inflicted on the body as the direct or indirect result of an external force, violence, or accident with or without disruption of structural continuity." The outcome of interest was the development of MS (that is, onset as opposed to relapse), evaluated either clinically or laboratory supported according to accepted criteria of the time. Studies were not excluded on the basis of language.

\section{Search strategy}

Relevant studies published from January 1, 1950 to May 31, 2011 were obtained through a computerized search of bibliographic databases, including Medline, Medline in process, Embase, All EBM Reviews - Cochrane Database of Systematic Reviews, American College of Physicians Journal Club, Database of Abstracts of Reviews of Effectiveness, Cochrane Central Register of Controlled Clinical Trials, Cochrane Methodology Register, Health Technology Assessment, and
NHS Economic Evaluation Database, Ovid HealthStar, Cumulative Index to Nursing and Allied Health Literature, ISI Web of Science, PubMed, and Scopus. Key words used were: multiple sclerosis, accident, injury, trauma, fracture, fall and concussion. They were selected with the help of a librarian specializing in health sciences databases and included terms used by the Cochrane Collaboration for studies involving MS. This procedure was complemented by manually searching the bibliographies of database-identified articles for key authors and journals. Narrative reviews were also hand-searched for their references. Scopus was used for each of the initially selected articles to track the references and who cited the original publications to ensure that no potentially relevant articles were missed in the search. Google search engine was used to identify studies which might have been published in the "grey literature" rather than peer-reviewed journals. Colleagues of the corresponding author (SW) were consulted to determine whether they knew of other unidentified articles.

\section{Study identification and data extraction}

Two reviewers (SAO, JF) screened the titles and abstracts of identified articles. Full texts of articles were retrieved for potentially relevant studies, and for those whose abstracts provided inadequate information to make a decision. The same reviewers independently screened the full text of all retrieved articles, using a standard form based on the inclusion criteria. If discrepancies occurred between the reviewers on whether to include an article, they compared rating forms and resolved discrepancies by discussion. The same reviewers (SAO, JF) extracted relevant data from each of the articles chosen for the systematic review. Information regarding authors, year, country, study design, data collection, sample size and characteristics, type of traumatic injury, statistical analysis and results was recorded. When information provided in the article was open to interpretation, it was discussed to reach consensus on how it should be reported.

\section{Quality assessment}

A critical appraisal was conducted to determine the methodological quality of the included studies (SAO, JF), using the Newcastle-Ottawa Scale (NOS) which provides different scales to analyze case-control and cohort designs. The NOS is the most frequently used tool to assess the quality of nonrandomized studies in health research and has been recommended by the Cochrane Non-Randomized Studies Methods Working Group, who note that its content validity and inter-rater reliability have been established. ${ }^{12}$ The NOS tool uses a "star system" in which a study is judged from three broad perspectives: the selection of study groups; the comparability of groups; and the ascertainment of either exposure or outcome of interest for case-control or cohort studies respectively. Each NOS scale includes eight items. The items for the case-control version include: 1) case definition adequate, 2) representativeness of cases, 3) source of controls, 4) definition of controls, 5) comparability on most important factor and others, 6) ascertainment of exposure, 7) same method of ascertainment for cases and controls, 8) non-response. The first five items in the cohort version are essentially the same but the other three (items 6 to 8 ) include: 6) ascertainment of outcome, 7) follow up long 
enough for outcome to occur, 8) adequacy of follow up of cohorts. Each item in either version is awarded a maximum of one star if appropriate standards have been achieved, with the exception of comparability which allows for two stars based on extent. Newcastle-Ottawa Scale scores range from zero to nine stars. We developed a scoring system to rate studies included in this review. The score for each was calculated by dividing the number of stars achieved by the number of items. Each study was graded as low, moderate or high quality based on this score. Cut-off points were designated a priori as: $0.00-0.44$ low methodological quality, 0.45-0.70 moderate quality, and 0.711.00 high quality. Such cut-off points are often used to determine reference values for level of association/agreement by researchers and have been acknowledged as acceptable by experts in research methods. ${ }^{13,14}$

\section{Meta-analysis technique}

Data regarding exposure and outcome were extracted from all studies providing quantitative information. A meta-analysis was performed to quantify the pooled effect of the association between traumatic injury and the onset of MS. Revman 5.0 Software $\dagger$ [Computer program, Copenhagen: The Nordic Cochrane Centre, The Cochrane Collaboration, 2008 http:// www.cc-ims.net/RevMan] was used to summarize the effects (odds ratio for case-control studies or SIR for cohort studies) and to construct visual tree-like forest plots (meta-graphs). For this analysis the $95 \%$ confidence interval (CI) was used. A test for heterogeneity (degree of variation between individual study results $)^{15}$ was performed using a Chi-square test $(\mathrm{p}<0.10) ;{ }^{16}$ an $\mathrm{I}^{2}$ value of $50 \%$ or more represents substantial heterogeneity. ${ }^{15}$ Acknowledging that the included studies had been conducted independently and might represent only a random sample of the distribution of all possible effect sizes for this association, the random effects model was utilized. This model incorporates an estimate of both between-study and within-study variation into the calculation of the summary effect measure to provide a more conservative estimate of the true effect. ${ }^{16,17}$ Two-sided $\mathrm{p}<0.05$ was considered statistically significant for data included in the meta-analysis. Each study was weighted by sample size and variability (automatically done by RevMan 5.0 software) following the standards for analysis suggested by the Cochrane Collaboration. ${ }^{18}$ Studies were not weighted for quality since weighting by study quality has been controversial and not recommended. ${ }^{19,20}$ Sensitivity analyses were conducted to determine the influence of study quality, type of traumatic injury, and use of specified MS diagnostic criteria on the association between traumatic injury and MS onset, since the number of studies in various strata was sufficient to address the influence of these factors.

\section{RESUlts}

A total of 8,099 articles were found in the database search. Of these, 75 were considered potential studies of interest based on title and abstract review. After full article review, 16 studies were deemed to fulfill the inclusion criteria. ${ }^{21-36}$ Fifty-nine studies were excluded for the following reasons: 23 articles were narrative reviews; ${ }^{5,6,9,37-56}$ seven articles were not about MS (e.g., lateral amyotrophic sclerosis); ${ }^{57-63}$ eight articles were case reports or case series, ${ }^{64-71} 13$ articles did not involve traumatic injury as an exposure; ${ }^{72-84}$ two were letters to the editor; ${ }^{85,86}$ one was not primary research (i.e., notes) $;{ }^{87}$ one was a commentary; ${ }^{7}$ one was a prevalence study with no information regarding the association between traumatic injury and MS onset; ${ }^{88}$ one article looked at traumatic injury after the onset of $\mathrm{MS} ;{ }^{89}$ and two articles examined the relationship between ionizing radiation and MS onset, which was not within the definition of traumatic injury for this review. ${ }^{90,91}$ A flowchart depicting this sequence is shown in Figure 1. The kappa agreement between reviewers in choosing articles according to the inclusion criteria was $100 \%$ ( $\mathrm{k}$ $=1.00)$.

Data were extracted from these 16 articles regarding authors/year, country, study design/data collection, sample size and characteristics, type of traumatic injury, analysis, and main results; and critical appraisal scores assigned to each article. The kappa agreement between the reviewers on critical appraisal scores for the included articles was $96 \%(\mathrm{k}=0.92)$ before being resolved through consensus. Summaries and quality scores for each article are provided in the Table.

\section{Nature of studies}

Of the 16 articles finally selected for this systematic review, 13 were classified as case-control-studies, ${ }^{21-27,29-31,34-36}$ and three as cohort studies. ${ }^{28,32,33}$ Traumatic injury was defined in a number of ways by these studies. Ten of the 16 articles examined the association between cranial (i.e., skull) or head (i.e., facial) traumatic injury and MS onset. Of these ten articles, five examined cranial/head only; ${ }^{27,28,30,32,34}$ three examined cranial/ head plus spinal cord/back traumatic injury; ${ }^{29,33,36}$ and two investigated the association between cranial/head, spinal cord/back plus any traumatic injury at the body level (e.g., fracture, major physical trauma, minor physical trauma, major and minor surgery, lumbar puncture, spinal anesthesia, electrical shock, falls) and MS onset. ${ }^{22,24}$ One study ${ }^{21}$ defined traumatic injury as any accident producing unconsciousness. One study included trauma defined as any accident and burns. ${ }^{35}$ Four studies $^{23,25,26,31}$ did not define the type of traumatic injury investigated.

\section{Direction of studies}

Eight of the case-control studies had an OR of greater than 1.0. However, only three of these studies ${ }^{27,29,31}$ had $95 \%$ CIs that did not include 1.0. Two of them ${ }^{27,31}$ found a significant association $(p<0.05)$ between traumatic injury and the onset of MS. The remaining study and one other ${ }^{26,29}$ observed an association which approached significance, with $\mathrm{p}$ values between $>0.05$ and $<0.10$. One of these ${ }^{29}$ compared head trauma overall, head trauma before and after age 15, back trauma overall, back trauma before and after age 15; with only head trauma before 15 approaching significance. None of the cohort studies found a significant association between traumatic injury and the onset of multiple sclerosis.

\section{Quality of studies}

Eight of the 13 case-control studies ${ }^{24-27,29,30,34,36}$ were considered to be of moderate quality (four scoring 0.55 and four $0.66)$. The remaining five studies ${ }^{21-23,31,35}$ were of low quality (one scoring 0.22, two 0.33, and two 0.44). Nine $22-26,29,30,35,36$ met the criterion of adequate case definition, but only three ${ }^{21,24,35}$ 


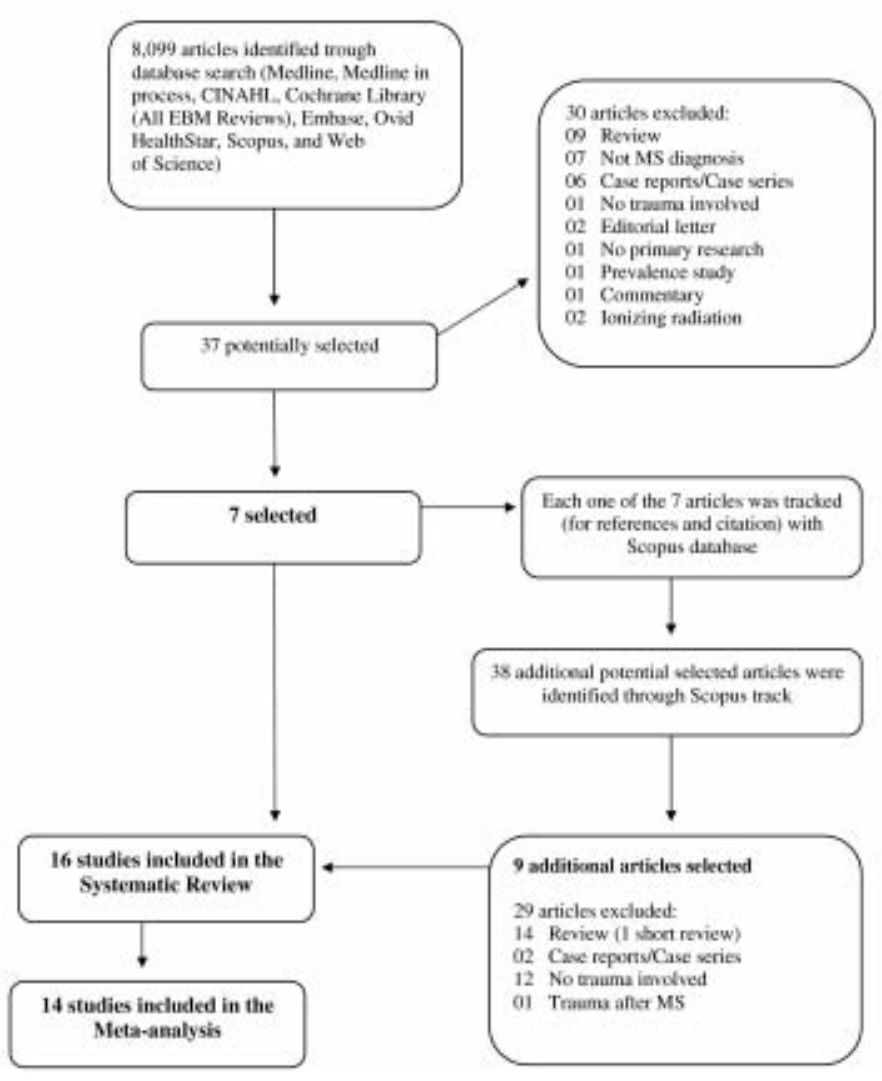

met the criterion of adequate control definition. Six ${ }^{26,27,29,30,34,36}$ ensured that cases were representative of persons with MS and four ${ }^{25,27,30,34}$ that controls were representative of the general population. Seven ${ }^{23-27,29,36}$ achieved the maximum score for group comparability. All of the studies used self-report data on exposure. Six verified exposure through family/friends ${ }^{24-26,29,35,36}$ and two through documentation, ${ }^{35,36}$ but little detail was given. Studies typically used the same method of ascertainment for cases and controls, that is, self-report, although doing so does not decrease the likelihood of recall bias. Five $24,27,30,34,36$ indicated response rate.

Two of the cohort studies ${ }^{28,32}$ were considered to be of high quality and one ${ }^{33}$ of moderate quality. All three accomplished most of the criteria evaluated by the NOS tool. However only two ${ }^{28,32}$ of the three studies clearly demonstrated that MS was not present in subjects at the beginning of the study and only two $^{28,33}$ that follow up was adequate in groups exposed/not exposed to traumatic injury. None of the cohort studies achieved the maximum score for comparability of groups exposed/not exposed to traumatic injury on the basis of design or analysis.

\section{Meta-analysis of case-control studies}

Twelve case-control studies provided quantitative information, allowing their inclusion in the meta-analysis; one ${ }^{25}$ did not. The OR effect estimate of the association between traumatic injury and MS onset for case-control studies included in the meta-analysis, was 1.41 (95\% CI: 1.03, 1.93), statistically

Figure 1: Article Selection Process

Table: Studies included in the systematic review

\begin{tabular}{|c|c|c|c|c|c|}
\hline $\begin{array}{l}\text { Authors/year/ } \\
\text { country }\end{array}$ & $\begin{array}{l}\text { Quality } \\
\text { score }\end{array}$ & Design & Sample & Type of trauma & Results \\
\hline $\begin{array}{l}\text { Alter and Speer, } \\
1968 \text {, USA }\end{array}$ & $0.33=$ Low & $\begin{array}{l}\begin{array}{l}\text { Case-control. } \\
\text { Interview questionnaire pre onset age. Recall. }\end{array} \\
\end{array}$ & $\begin{array}{l}\text { Cases from hospital MS Clinic, U Minnesota Hospital, similar to known distribution of } \\
\text { MS patients. Controls from hospital outpatient clinic. Matched on gender, age. }\end{array}$ & \begin{tabular}{|l} 
Accident producing unconsciousness. \\
\end{tabular} & $\begin{array}{l}\mathrm{X}^{2} \text { test. No significant difference between cases } \\
\text { and controls with trauma. }\end{array}$ \\
\hline $\begin{array}{l}\text { Bamford et al., } \\
\text { 1981, USA }\end{array}$ & $0.33=$ Low & $\begin{array}{l}\text { Case-control. Interview questionnaire pre onset age, focusing on } \\
\text { types and severity of trauma. Recall. }\end{array}$ & $\begin{array}{l}\text { Implied source of cases University of Arizona Health Sciences Center. Rose et al. } \\
\text { criteria, }{ }^{101} \text { only probable/definite. Familial controls. Matched on gender, age. }\end{array}$ & $\begin{array}{l}\text { Any trauma, fracture, surgery, childbirth, } \\
\text { lumbar puncture, spinal anesthesia, } \\
\text { electrical shock. }\end{array}$ & $\begin{array}{l}\text { Paired t-test. Events/per year not significantly } \\
\text { different between cases and controls. }\end{array}$ \\
\hline $\begin{array}{l}\text { Berr et al., } 1989, \\
\text { France }\end{array}$ & $0.44=$ Low & \begin{tabular}{|l|}
$\begin{array}{l}\text { Case-control. } \\
\text { Interview questionnaire pre onset age. Recall. }\end{array}$ \\
\end{tabular} & $\begin{array}{l}\begin{array}{l}\text { Cases in Haute-Pyrenees. Poser criteria, }{ }^{\text {100 }} \text { all probable/definite. Controls from same } \\
\text { parish. Matched on gender, age. Cases } 73 \% \text { female; mean onset } 30 \text { years. }\end{array} \\
\end{array}$ & Not specified. & \begin{tabular}{|l}
$\begin{array}{l}\text { Matched } X^{2} \text { test. Number of cases reporting } \\
\text { trauma vs. controls, not significant. }\end{array}$ \\
\end{tabular} \\
\hline $\begin{array}{l}\text { Bobowick et al., } \\
\text { 1978, USA }\end{array}$ & $\begin{array}{l}0.66= \\
\text { Moderate }\end{array}$ & $\begin{array}{l}\text { Case-control. } \\
\text { Interview questionnaire prior to age } 20 \text {. Recall, relative } \\
\text { verification. }\end{array}$ & $\begin{array}{l}\text { Twins from Twin Registry, National Sciences Academy, MS by ICD code. Neurologist } \\
\text { confirmed. White male pairs, born 1917-1927, veterans. } 5 \text { mono/4 dizygotic pairs, } 2 \\
\text { concordant for MS. }\end{array}$ & \begin{tabular}{|l} 
Head trauma and fracture. \\
\end{tabular} & $\begin{array}{l}\text { Exact test. Risk ratio }=4.7 \text { for trauma but } \mathrm{p}= \\
0.23 \text {. }\end{array}$ \\
\hline $\begin{array}{l}\text { Casseta et al., 1994, } \\
\text { Italy }\end{array}$ & $\begin{array}{l}0.55= \\
\text { Moderate }\end{array}$ & \begin{tabular}{|l|} 
Case-control. \\
Interview questionnaire pre onset age. Recall, relative verification.
\end{tabular} & $\begin{array}{l}\text { Cases in Ferrara. McAlpine criteria," all definite. Controls, hospital or population. } \\
\text { Similar on gender, age. Mean case age } 46,70 \text { females } 34 \text { males. }\end{array}$ & \begin{tabular}{|l} 
Not specified. \\
\end{tabular} & $\begin{array}{l}\begin{array}{l}\text { Odds ratio and CI used. No data provided, no } \\
\text { association reported. }\end{array} \\
\end{array}$ \\
\hline $\begin{array}{l}\text { Currier et al., 1974, } \\
\text { Ireland }\end{array}$ & $\begin{array}{l}0.55= \\
\text { Moderate }\end{array}$ & $\begin{array}{l}\text { Case-control. } \\
\text { Interview questionnaire, birth to onset age. Recall, relative/friend } \\
\text { verification. }\end{array}$ & $\begin{array}{l}\text { Cases from neurologists, MS Society and Medico-Social Research Board. Allison and } \\
\text { Millar criteria, }{ }^{96} \text { judged by } 2 \text { neurologists. Controls from relatives/friends, neurology } \\
\text { patients from Dublin hospital, paraplegics from national rehab centre. Matched on } \\
\text { gender, age, social class, marital status. All native Irish. Mean case age } 41 \text {. }\end{array}$ & $\begin{array}{l}\text { Unspecified injury to body or face, falls } \\
\text { and fracture. Data also collected on } \\
\text { surgery and dental work. }\end{array}$ & $\begin{array}{l}\text { T-test. Number of events in cases reported as } \\
\text { different from controls but } p>0.05<0.10 \text {. }\end{array}$ \\
\hline $\begin{array}{l}\text { Ghadrian et al., } \\
\text { 2001, Canada }\end{array}$ & $\begin{array}{l}0.66= \\
\text { Moderate }\end{array}$ & $\begin{array}{l}\begin{array}{l}\text { Case-control. } \\
\text { Interview questionnaire, } 1 \text { year pre onset age. Recall. }\end{array} \\
\end{array}$ & $\begin{array}{l}\text { Cases MS Society (Montreal East), doctor referrals, ads (74\% response). Controls } \\
\text { randomly dialed ( } 85 \% \text { response). Matched on gender, residence. Similar age. }\end{array}$ & $\begin{array}{l}\text { Cranial trauma without loss of } \\
\text { consciousness. }\end{array}$ & $\begin{array}{l}\text { Logistic regression. Cases more likely to report } \\
\text { trauma before onset age. }\end{array}$ \\
\hline $\begin{array}{l}\text { Goldacre et al., } \\
\text { 2005, UK }\end{array}$ & $\begin{array}{l}0.88= \\
\text { High }\end{array}$ & \begin{tabular}{|l|} 
Cohort. \\
Persons with head injury from hospital admission and death \\
records, Oxford NHS region (1963-1999). Reference cohort same \\
source. Mean follow up 17 years.
\end{tabular} & $\begin{array}{l}\text { 110,993 persons with head injury, } 534,600 \text { without. Excluded those over } 85 \text { and MS } \\
\text { recorded before trauma. } 72 \% \text { of people with head injury were under age } 35 \text {. }\end{array}$ & Head injury by ICD code. & $\begin{array}{l}\text { Rate ratio }(95 \% \mathrm{CI}) \text {, adjusted for gender, age, } \\
\text { year of admission and residence, for head } \\
\text { injury vs. reference cohort, not significant. }\end{array}$ \\
\hline $\begin{array}{l}\text { Gusev et al., 1996, } \\
\text { Russia }\end{array}$ & $\begin{array}{l}0.55= \\
\text { Moderate }\end{array}$ & $\begin{array}{l}\text { Case-control. } \\
\text { Interview questionnaire, pre age } 15 \text { and } 15 \text { to onset age. Recall, } \\
\text { relatives answered for young subjects. }\end{array}$ & $\begin{array}{l}\text { Cases from Moscow First City Hospital and environs. McAlpine criteriaia }{ }^{97} 145 \\
\text { probable/definite. Controls, patients from hospital, staff, medical students, non-blood } \\
\text { relatives. Matched on gender, age, ethnicity, with similar education. Cases mean age } \\
37,96 \text { females. }\end{array}$ & $\begin{array}{l}\text { Head trauma with lost consciousness or } \\
\text { back trauma. }\end{array}$ & $\begin{array}{l}\text { Multivariate analyses. Only head trauma pre } \\
\text { age } 15 \text { reported to be significantly associated } \\
\text { with MS but p }=0.06 \text {. }\end{array}$ \\
\hline $\begin{array}{l}\text { Koch-Henriksen, } \\
\text { 1989, Denmark }\end{array}$ & $\begin{array}{l}0.66= \\
\text { Moderate }\end{array}$ & $\begin{array}{l}\text { Case-control. } \\
\text { Cases interviewed in person, controls phone with questionnaire } \\
\text { pre age } 15 \text { and } 15 \text { to onset age. Recall. }\end{array}$ & $\begin{array}{l}\text { MS cases in Funen from Danish MS Registry, hospitals and neurologists. Allison and } \\
\text { Millar criteria, }{ }^{6,6} \text { most probable/definite. Controls randomly drawn from Central } \\
\text { Population Registry. Frequency matched by gender, age. }\end{array}$ & $\begin{array}{l}\text { Head trauma with } \\
\text { concussion. }\end{array}$ & $\begin{array}{l}\text { McNemar } \mathrm{X}^{2} \text { for pairs with complete data. No } \\
\text { significant differences between cases and } \\
\text { controls for either time period. }\end{array}$ \\
\hline $\begin{array}{l}\text { McAlpine and } \\
\text { Compston, 1952, } \\
\text { UK }\end{array}$ & $\begin{array}{l}0.22= \\
\text { Low }\end{array}$ & $\begin{array}{l}\text { Case-control. } \\
\text { Interview questionnaire, across lifespan and for } 3 \text { months pre } \\
\text { onset of their disease. Recall. }\end{array}$ & $\begin{array}{l}\text { Cases available } 1948-5 \text { from Middlesex and Maida Vale Hospital records, from } \\
\text { Ministry of Pensions, and patients of one author (<50\% of known cases). Randomly } \\
\text { selected controls from Middlesex Hospital. Similar on gender, age. }\end{array}$ & $\begin{array}{l}\text { Trauma not defined, but surgery and } \\
\text { dental extractions included. }\end{array}$ & $\begin{array}{l}\mathrm{X}^{2} \text { test. More MS cases than controls reported } \\
\text { trauma in } 3 \text { months before onset, } \mathrm{p}<0.01 \text {. }\end{array}$ \\
\hline $\begin{array}{l}\text { Pfleger et al., 2009, } \\
\text { Denmark }\end{array}$ & $\begin{array}{l}0.77= \\
\text { High }\end{array}$ & $\begin{array}{l}\text { Cohort. } \\
\text { Persons admitted to hospital for head trauma in Danish National } \\
\text { Patient Registry, 1977-99, linked to Danish MS Registry to find } \\
\text { those with MS onset after trauma up to death, emigration or } 1999 .\end{array}$ & $\begin{array}{l}150,868 \text { persons admitted for head trauma under age } 55 \text {. . MS criteria Allison and } \\
\text { Millar, } 9 \text { also Poser, } 100 \text { possible/probable/definite but not cases with single episode or } \\
\text { poor documentation. } 114 \text { excluded for onset pre trauma. } 37 \% \text { female, } 80 \% \text { under age } \\
35 \text { at time of trauma. }\end{array}$ & $\begin{array}{l}\text { Head trauma with concussion, contusion } \\
\text { or skull fracture by ICD code. Most had } \\
\text { suffered mild-moderate head trauma, but } \\
16,426 \text { severe head trauma. } \\
\end{array}$ & $\begin{array}{l}\text { Overall SIR with possible MS included was not } \\
\text { significant. Also not significant with possible } \\
\text { cases excluded. No differences by trauma } \\
\text { severity or gender. }\end{array}$ \\
\hline $\begin{array}{l}\text { Siva et al., 1993, } \\
\text { USA }\end{array}$ & $\begin{array}{l}0.66= \\
\text { Moderate }\end{array}$ & $\begin{array}{l}\text { Cohort. } \\
\text { Head injury and lumbar disc surgery cohorts from Mayo Clinic } \\
\text { records. }\end{array}$ & $\begin{array}{l}\text { Workshopon Diagnosis of MS criteriai }{ }^{98} 819 \text { persons with head injury and } 492 \text { with } \\
\text { surgery followed. Trauma groups within the age range for risk of MS. }\end{array}$ & $\begin{array}{l}\text { Head trauma with skull fracture, loss of } \\
\text { consciousness, focal neurological signs, } \\
\text { amnesia. Spinal trauma with compression } \\
\text { of vertebral body or other fractures. }\end{array}$ & $\begin{array}{l}2 \text { in head injury cohort developed MS, at } 3 \text { and } \\
21 \text { years. } 1 \text { in surgery cohort developed MS at } 3 \\
\text { years. Later articles compared results to MS } \\
\text { incidence rate in population. }\end{array}$ \\
\hline $\begin{array}{l}\text { Westlund, 1952, } \\
\text { USA and Canada }\end{array}$ & $\begin{array}{l}0.55= \\
\text { Moderate }\end{array}$ & \begin{tabular}{|l|} 
Case-control. \\
Interview questionnaire pre onset age. Recall.
\end{tabular} & $\begin{array}{l}\text { Cases in Winnipeg and New Orleans from private physicians, hospitals, MS Society; } \\
\text { cases possible/probabble/definite on agreement by } 2 \text { blinded neurologists. Systematic } \\
\text { random sample controls, stratified by gender and age, from Canadian Sickness Survey } \\
\text { participants. All cases in Winnipeg white, some in New Orleans non-white. All } \\
\text { controls white. Cases age range } 24-65,59 \% \text { female. }\end{array}$ & \begin{tabular}{|l|} 
Head injury with unconsciousness. \\
\end{tabular} & $\begin{array}{l}\text { No statistics applied. \% cases and controls } \\
\text { reporting head injury before onset age the same }\end{array}$ \\
\hline $\begin{array}{l}\text { Wilhelm, 1970, } \\
\text { Germany }\end{array}$ & $\begin{array}{l}0.44= \\
\text { Low }\end{array}$ & $\begin{array}{l}\text { Case-control. } \\
\text { Information on childhood from records, supplemented by subjects } \\
\text { or parents. }\end{array}$ & $\begin{array}{l}\text { Cases (laboratory supported), controls from Basel University Hospital, both groups } \\
\text { representative of region. Similar on gender, age. }\end{array}$ & Accidents and burns. & $\begin{array}{l}\mathrm{X}^{2} \text { test. No significant difference on proportion } \\
\text { of cases, controls with trauma. }\end{array}$ \\
\hline $\begin{array}{l}\text { Zorzon et al., } 2000, \\
\text { Italy }\end{array}$ & $\begin{array}{l}0.66= \\
\text { Moderate }\end{array}$ & $\begin{array}{l}\text { Case-control. } \\
\text { Interview questionnaire pre onset age. Recall, verified by relatives } \\
\text { or documentation. }\end{array}$ & $\begin{array}{l}\text { Consecutive cases attending MS Centre, University of Trieste }(87 \% \text { response). } \\
\text { Controls from donors at local Blood Transfusion Centre }(94 \% \text { response). Matched on } \\
\text { gender, age, similar on residence, ethnicity. Mean case age } 42,90 \text { women } / 50 \text { men. } \\
71 \% \text { RRMS, } 19 \% \text { SPMS and } 9 \% \text { PPMS. Most mild disability, mean disease duration } \\
11 \text { years. }\end{array}$ & $\begin{array}{l}\text { Cranial or spinal trauma, either accidental } \\
\text { or surgical and fractures. }\end{array}$ & $\begin{array}{l}\text { Multivariate analyses. Cranial or spinal trauma } \\
\text { not associated with MS onset. Nor fractures. }\end{array}$ \\
\hline
\end{tabular}




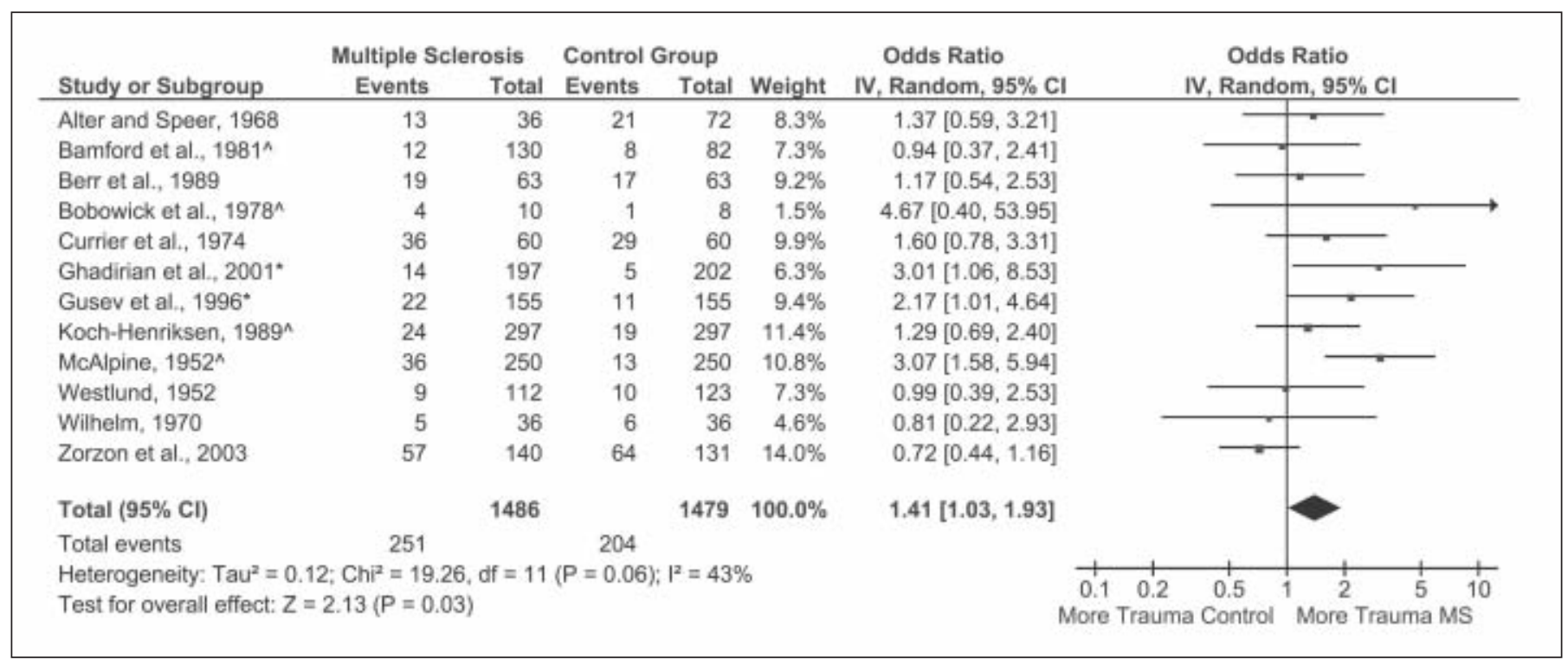

Figure 2: Meta-analysis of Case-Control Studies. * Values taken from the multivariate models reported in original articles; ${ }^{\wedge}$ Data extraction adapted for pooling results in meta-analysis

significant $(\mathrm{p}=0.03)$. Heterogeneity was acceptable at $43 \%$. The results are depicted in Figure 2; events and sample sizes for cases and controls, ORs and 95\% CIs are shown for each included study. A funnel plot was constructed to assess the possibility of publication bias for the case-control studies. Visual inspection of the plot did not suggest asymmetry, indicating that publication bias was not an issue in this systematic review. ${ }^{92}$

\section{Case-Control studies: results by quality}

When studies of moderate quality were analyzed, ${ }^{24,26,27,29,30,34,36}$ the OR was 1.40 (95\% CI: 0.91, 2.13), not statistically significant $(\mathrm{p}=0.12)$. When studies of low quality were analyzed, ${ }^{21-23,31,35}$ a higher OR of 1.44 was obtained (95\% CI: $0.87,2.38)$, again not statistically significant $(\mathrm{p}=$ $0.16)$. Heterogeneity was acceptable among both the moderate quality $(48 \%)$ and low quality $(41 \%)$ studies. The fact that neither the moderate nor low quality case-control studies produced a significant effect size (1.40 and 1.44 respectively) suggests that the effect size found overall (1.41) was an inconsequential one pushed into significance by the added sample size of the meta-analysis.

\section{Case-Control studies: results by type of trauma}

When studies that considered only an association between cranial/head traumatic injury and MS onset were analyzed, 27,30,34 the OR was $1.46(95 \%$ CI: $0.83,2.55)$, not statistically significant $(\mathrm{p}=0.18)$. When studies that examined cranial/head only, cranial/head plus spinal cord/back traumatic injury, or those two categories plus other types of injury were analyzed together, ${ }^{22,24,27,29,30,34,36}$ the OR was 1.30 (95\% CI: $\left.0.84,2.00\right)$, likewise not statistically significant $(\mathrm{p}=0.24)$. When studies that did not define the type of traumatic injury were analyzed, ${ }^{21,23,26,31,35}$ the OR rose to 1.62 (95\% CI: $\left.1.06,2.48\right)$, statistically significant $(\mathrm{p}=0.03)$. Heterogeneity was lower when the analysis included studies that investigated cranial/head traumatic injury only (25\%) and unspecified types of injury $(27 \%)$ rather than studies that investigated cranial/head only, $\mathrm{cranial} /$ head plus spinal cord/back traumatic injury and those two categories plus other injury types (47\%). Studies which did not define type of traumatic injury may have been more susceptible to recall bias, considering the wide scope of possible injuries which persons with MS could include.

\section{Case-control studies: results by use of MS diagnostic criteria}

When studies that did not use specified MS diagnostic criteria were analyzed,,$^{21,24,27,31,34,35,36}$ the OR was 1.59 (95\% CI: 0.85 , $3.00)$, not statistically significant $(\mathrm{p}=0.15)$. Among the studies specifying diagnostic criteria, a wide range of historically appropriate ones were used, with authors generally selecting the most widely accepted criteria for the year of their study. When studies that used specified MS diagnostic criteria were analyzed, ${ }^{22,23,26,29,30}$ an OR of 1.36 was obtained (95\% CI: 0.98 , $1.88)$, again not statistically significant $(\mathrm{p}=0.06)$. Heterogeneity was unacceptably high $(61 \%)$ among studies that did not use specified criteria but was reduced to $0 \%$ among studies that did. Although misclassification of study participants into MS/not groups is more likely to occur when no specified criteria are used, findings did not vary by this factor.

\section{Meta-analysis of cohort studies}

One of the cohort studies ${ }^{33}$ was excluded because it did not have a reference cohort with no trauma embedded in the study; MS incidence in the trauma cohorts was very low, showing no excess compared to the general population. The SIR for the two included studies was 1.00 (95\% CI: $0.86,1.16)$, not statistically significant $(p=0.97)$. Heterogeneity was acceptable at $29 \%$. Figure 3 depicts these results; events and sample size are embedded in the Table. 


\section{CONCLUSIONS AND DISCUSSION}

\section{Association between traumatic injury and MS onset}

The OR for case-control studies in this review supported an association between traumatic injury and MS onset. However, the average effect size of 1.41 is below the 2.0 threshold beyond which an elevated OR is probably not due to bias ${ }^{93}$ and the 3.0 recommended to avoid significance due to overpowering in meta-analyses. ${ }^{94}$ Although weighting of studies included in a meta-analysis by quality is controversial, some methodologists ${ }^{95}$ have suggested that low quality studies should be excluded entirely. If not, studies with low validity will contribute as much to the summary measure as those with comparable sample size but greater validity and may bias the results. The same methodologists have recommended the option of excluding outliers. ${ }^{95}$ Among the low quality studies in this review, McAlpine and Compston ${ }^{31}$ had the lowest quality score and close to the largest sample size. Excluding this study alone as an outlier would have reduced the OR among case-control studies to 1.24 (95\% CI: $0.94,1.64), p=0.12$ and heterogeneity to $19 \%$. If only the moderate quality case-control and high quality cohort studies had been considered, this review like earlier ones would not support an association between traumatic injury and the onset of MS.

\section{Strengths}

Our systematic review includes articles not covered in the AAN report, current to May 2011. A standardized scoring system recommended by the Cochrane Group, the NOS, was used to assign quality scores to included articles, unlike previous reviews. There appear to be no meta-analyses published on the association between traumatic injury and MS onset. Since separate meta-analyses were conducted for case-control studies with low and moderate quality and for cohort studies which were of high quality, we have provided insight into the association between traumatic injury and MS onset by quality of study. The exploration of this association by type of trauma and use of specified diagnostic criteria are also unique contributions to the literature.

\section{Limitations}

Although case-control and cohort studies are appropriate to determine association and causality, these designs have weaknesses which limit their ability to elucidate the role of possible risk factors. Case-control studies often rely on subject recall of trauma without verification by factual sources, such as medical records. Subjects or family/friends interviewed for verification may be biased in their recall of trauma, trying to find an explanation for onset of the disease; this may account for the large number of case-control studies in our systematic review which found an excess of trauma. In addition, because onset of MS is frequently occult, it is seldom possible to establish that trauma occurred prior to onset. It might even be argued that the number of case-control studies with an odds ratio of greater than 1.0 is a reflection of occult onset precipitating trauma, i.e., participants are reporting trauma on the assumption that it preceded symptoms when in fact unrecognized symptoms were increasing their risk of trauma. Although, theoretically, cohort studies should be better, this depends somewhat on their sources of data. For example, are injured versus non-injured groups assembled on the basis of self-report or medical records? Have they been screened for MS prior to trauma? This is not always so, especially when subjects are identified from databases not set up for the purpose. Another issue is the appropriate timeframe for observational studies. For example, how far in the past can trauma have occurred in case-control studies and how far in the future should subjects be followed for the development of MS in cohort studies? In addition the comparability of groups can have a bearing on any association observed; for example, the physical activity level of cases versus controls or family history of MS in injured versus non-injured cohorts. Most of the studies in this systematic review controlled for gender and age in some way, such as matching, but few used multivariable models to adjust for other potentially confounding variables. The three studies ${ }^{27-29}$ that used adjustment did control for factors such as education, energy intake and smoking, as well as for gender and age. The crude estimates versus the adjusted estimates in these studies were similar, suggesting no impact of these variables. However, future studies might benefit from more attention to such factors since at least one study ${ }^{29}$ found that medical training influenced propensity to report the occurrence of trauma, illustrating the possible influence of confounding variables.

The definition of traumatic injury is also problematic. As seen from this systematic review, the definition of trauma in research has been diverse. Some studies combined events, reporting data in such a way that various types of traumatic injury could not be separated out in the meta-analysis. More studies examining the association between specific types of trauma and MS onset might be conducted. Other exposures which have sometimes been classified under the physical trauma umbrella, for example

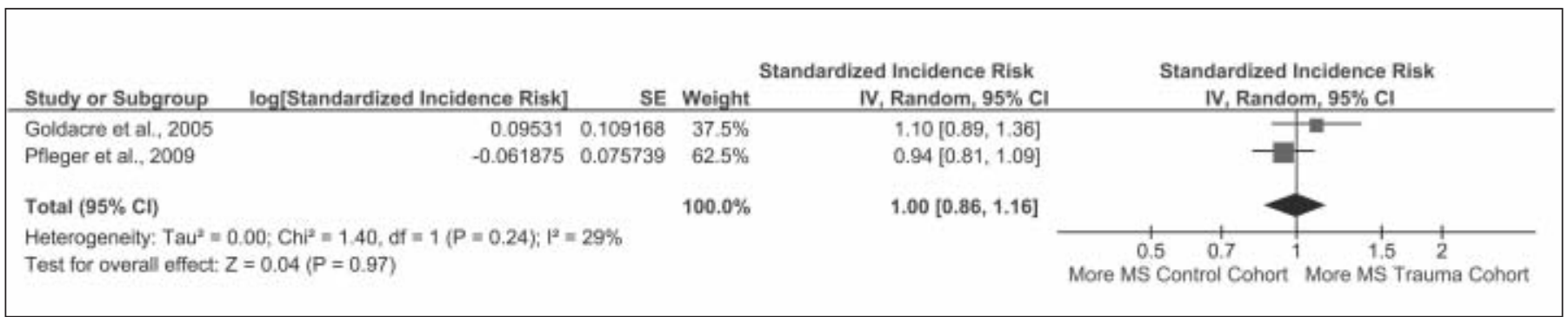

Figure 3: Meta-analysis of Cohort Studies 
to ionizing radiation, organic solvents and surgery/anesthesia were not included in the review, so that no conclusions can be reached about such exposures as risk factors for the onset of MS. Finally age at trauma prior to MS onset is an issue. Some studies divided time periods before onset, for example, before/after age 15 , in such a way that data could not be combined over the entire pre-onset period.

This review limited the definition of MS to onset of disease. While it may seem reasonable to assume that, if traumatic injury is not associated with MS onset, it would not be associated with relapse/exacerbations, no conclusion about an association between traumatic injury and relapse can be drawn from this review. The AAN report ${ }^{6}$ considered relapses, however, and still reached the conclusion that there was insufficient evidence linking physical trauma to MS. The diagnosis of MS can also be questioned and many criteria ${ }^{96-101}$ were used in the articles included in this review, depending upon those which were generally accepted at the time of each study. In particular, earlier studies relied on clinical rather than laboratory supported diagnosis and may have involved a greater degree of misclassification among subjects. Any future studies should use specified diagnostic criteria.

There is also the issue of power and statistical methods to be considered. Some of the case-control studies in this review may have had too few subjects to find a statistically significant association between traumatic injury and MS onset, despite greater exposure among the cases. However, two of the cohort studies included sufficient numbers to find even a small effect of traumatic injury. The approach to analyzing data in the articles included differed, for example, absence/presence of trauma versus number of traumatic events. The meta-analysis, however, extracted original data and used consistent statistical methods to describe study findings, that is, odds ratio, standardized incidence ratio and $95 \%$ confidence intervals.

\section{Implications}

An association between traumatic injury and the development of MS has been debated for many years. Studies have attempted to determine whether traumatic injury is a risk factor for MS, with conflicting results. On the whole this systematic review and meta-analysis does not support an association between traumatic injury and MS onset but it cannot rule out such an association, largely because of limitations in the studies conducted. Nevertheless the findings may be useful in adjudicating claims by persons with MS seeking compensation for traumatic injury from worker's compensation boards or insurance companies through the courts, especially considering the unconvincing effect size found for high quality cohort studies. The results should also help persons with MS, their families and caregivers to better assess the role of traumatic injury in the onset of their disease. Patients have a natural tendency to try to understand what factors contribute to the development of MS or may influence prognosis. They may even make decisions regarding their own and family members' behavior based on their beliefs about risk factors; for example, if a patient held the belief that trauma was a risk factor, they might discourage relatives from participating in physical work or recreational activities which could lead to injury and possibly precipitate MS. Clinicians should be able to use the findings to provide patients with information to help them make informed decisions about such avoidance behaviors.

Although the results of this systematic review and metaanalysis do not support an association between traumatic injury and the development of multiple sclerosis, only three cohort studies have been published. Further high quality cohort studies designed to address problems with previous research noted in the discussion, including clear indication that MS was not present before trauma and assurance of group comparability, would add valuable information regarding the role of traumatic injury in MS onset.

\section{Contributors}

All authors were responsible for study design. SAO and JF collected the data and conducted the meta-analyses. SW drafted the manuscript as submitted. All authors critically revised the manuscript.

\section{ACKNOWLEDGEMENTS}

The authors thank Ben Vandermeer, a biostatistician with the Alberta Research Centre for Health Evidence, who consulted on the meta-analyses. This study was funded by a grant from WorkSafeBC. WorkSafeBC, the funding source, had a role in the design of the study through a review of the protocol during the competition for funding. They had no role in data collection, analysis, interpretation of the data or writing the report, nor in the decision to publish or where to submit. Copies of the full report are available from WorkSafeBC.

\section{REFERENCES}

1. Compston A, Confavreux C. The distribution of multiple sclerosis. In: Compston A, Confavreux C, Lassman H, et al., editors. McAlpine's multiple sclerosis, 4th ed. Philadelphia: Churchill Livingstone/Elselvier; 2005. p. 71-111.

2. Warren S, Warren KG. Multiple sclerosis. Geneva: World Health Organization; 2001.

3. Riise T. Anayzing risk factor interactions in MS. Mult Scler. 2010;16:S17-18

4. Charcot J. Lectures on diseases of the nervous system. London: New Sydenham Society; 1879. p. 157-222.

5. Poser CM. The role of trauma in the pathogenesis of multiple sclerosis: a review. Clin Neurol Neurosurg. 1994;96:103-10.

6. Goodin DS, Ebers GC, Johnson KP, Rodriguez M, Sibley WA, Wolinsky JS. The relationship of MS to physical trauma and psychological stress: report of the Therapeutics and Technology Assessment Subcommittee of the American Academy of Neurology. Neurology. 1999;52:1737-45.

7. Corcoran M. An unhappy coincidence between multiple sclerosis and trauma? Lancet. 2002;359:726.

8. Davidson L. Can trauma provoke multiple sclerosis? A lawyer's view. Prac Neurol. 2003;3:372-5.

9. Weatherby MJ, Weatherby SJ, Hawkins CP. Does trauma trigger multiple sclerosis? 2: A medicolegal view. Hosp Med. 2003;64: 651-3.

10. Weintraub MI. Trauma and multiple sclerosis: medicolegal implications. Dev Med Child Neurol. 1988;30:407-8.

11. Stroup D, Berlin JA, Morton SC, et al. Meta-analysis of observational studies in epidemiology: a proposal for reporting. JAMA. 2000;283:2008-12.

12. Wells G, Shea B, O'Connell D, et al. The Newcastle-Ottawa Scale (NOS) for assessing the quality of nonrandomized studies in meta-analyses. Available from: http://www.ohri.ca/programs/ clinicalepidemiology/oxford.asp.

13. Byrt T. How good is that agreement? Epidemiology. 1996;7:561. 
14. Portney LG, Watkins MP. Foundations of clinical research: applications to practice. 3rd ed. Upper Saddle River, NJ: Pearson/Prentice Hall, 2008.

15. Higgins J, Deeks J, Altman D. Chapter 16: Special topics in statistics. In: Higgins J, Green S, editors. Cochrane handbook for systematic reviews of interventions, version 500 [updated February 2008] The Cochrane Collaboration, 2008. Available from: www.cochrane-handbook.org.

16. Deeks J, Higgins J, Altman D. Chapter 9: Analysing data and undertaking meta-analyses. In: Higgins J, Green S, editors. Cochrane handbook for systematic reviews of interventions, version 500 [updated February 2008] The Cochrane Collaboration, 2008. Available from: www.cochranehandbook.org.

17. Berard A, Bravo G. Combining studies using effect sizes and quality scores: application to bone loss in postmenopausal women. J Clin Epidemiol. 1998;51:801-7.

18. Higgins J, Green S. Cochrane Handbook for Systematic Reviews of Interventions 4.2.6 [updated September 2006]. In: Higgins J, Green S, editors. The Cochrane Library, Issue 4, 2006. Chichester, UK: John Wiley \& Sons; 2006.

19. Herbison P, Hay-Smith J, Gillespie WJ. Adjustment of metaanalyses on the basis of quality scores should be abandoned. $J$ Clin Epidemiol. 2006;59:1249-56.

20. Juni P, Altman DG, Egger M. Systematic reviews in health care: assessing the quality of controlled clinical trials. BMJ. 2001; 323:42-6

21. Alter M, Speer J. Clinical evaluation of possible etiologic factors in multiple sclerosis. Neurology. 1968;18:109-16.

22. Bamford CR, Sibley WA, Thies C, Laguna JF, Smith MS, Clark K. Trauma as an etiologic and aggravating factor in multiple sclerosis. Neurology. 1981;31:1229-34.

23. Berr C, Puel J, Clanet M, Ruidavets JB, Mas JL, Alperovitch A. Risk factors in multiple sclerosis: a population-based casecontrol study in Hautes-Pyrenees, France. Acta Neurol Scand. 1989;80:46-50

24. Bobowick AR, Kurtzke JF, Brody JA. Twin study of multiple sclerosis: an epidemiologic inquiry. Neurology. 1978;28:978-87.

25. Casetta I, Granieri E, Malagu S, et al. Environmental risk factors and multiple sclerosis: a community-based, case-control study in the province of Ferrara, Italy. Neuroepidemiology. 1994;13: $120-8$

26. Currier RD, Martin EA, Woosley PC. Prior events in multiple sclerosis. Neurology. 1974; 24:748-54.

27. Ghadirian P, Dadgostar B, Azani R, Maisonneuve P. A case-control study of the association between socio-demographic, lifestyle and medical history factors and multiple sclerosis. Can J Public Health. 2001; 92:281-5.

28. Goldacre MJ, Abisgold JD, Yeates DG, Seagroatt V. Risk of multiple sclerosis after head injury: record linkage study. J Neurol Neurosurg Psychiatry. 2006;77:351-3.

29. Gusev E, Boiko A, Lauer K, Riise T, Deomina T. Environmental risk factors in MS: a case-control study in Moscow. Acta Neurol Scand. 1996;94:386-94.

30. Koch-Henriksen N. An epidemiological study of multiple sclerosis. Acta Neurol Scand. 1989;80:S1-123.

31. McAlpine D, Compston N. Some aspects of the natural history of disseminated sclerosis. Quart J Med. 1952;21(82):135-67.

32. Pfleger CC, Koch-Henriksen N, Stenager E, Flachs EM, Johansen C. Head injury is not a risk factor for multiple sclerosis: a prospective cohort study. Mult Scler. 2009;15:294-8.

33. Siva A, Radhakrishnan K, Kurland LT, O'Brien PC, Swanson JW, Rodriguez M. Trauma and multiple sclerosis: a population-based cohort study from Olmsted County, Minnesota. Neurology. 1993;43:1878-82.

34. Westlund KB. Studies on multiple sclerosis in Winnipeg, Manitoba and New Orleans. Baltimore: John Hopkins University, 1952.

35. Wilhelm von E. Reziehungen zwischen erkrankengen ins kindesalter und multiple-sklerose-erkrankung. Schweiz Arch Neurol Neurchir Psychiatr. 1970;106:311-7.

36. Zorzon M, Zivadinov R, Nasuelli D, et al. Risk factors of multiple sclerosis: a case-control study. Neurol Sci. 2003;24:242-7.
37. Ascherio A, Munger KL. Environmental risk factors for multiple sclerosis. Part II: Non-infectious factors. Ann Neurol. 2007;61: 504-13.

38. Barnett MH, Sutton I. The pathology of multiple sclerosis: a paradigm shift. Curr Opin Neurol. 2006;19:242-7.

39. Barzarian JJ, Cernack I, Noble-Haesusslein L, Potolicchio S, Temkin N. Long-term neurologic outcomes after traumatic brain injury. J Head Trauma Rehab. 2009;24:439-51.

40. Boiko A, Deomina T, Favorova O, Gusev E, Sudomoina M, Turetskaya R. Epidemiology of multiple sclerosis in Russia and other countries of the former Soviet Union: investigations of environmental and genetic factors. Acta Neurol Scand. 1995;91: 71-6.

41. Britell CW. MS and trauma: is there a relationship? Mult Scler Q Rep. 1998;17:9-11.

42. Christensen JC. Multiple sclerosis: some epidemiological clues to etiology. Acta Neurol Latinoamer. 1975;21:66-85.

43. Compston A, Coles A. Multiple sclerosis. Lancet. 2002;359: 1221-31.

44. Confavreux C, Vukusic S. The clinical epidemiology of multiple sclerosis. Neuroimaging Clin N Am. 2008;18:589-622.

45. Dyll LM. Trauma and multiple sclerosis: problems in epidemiology. Trauma. 1999;41:51-64.

46. Jellinek EH. Trauma and multiple sclerosis. Lancet. 1994;343: 1053-4.

47. Kremenchutzky M. The natural history of multiple sclerosis. Rev Neurol. 2000;30(10):967-72.

48. Kurland LT. Trauma and multiple sclerosis. Ann Neurol. 1994;36: S33-7.

49. Lauer K. Environmental risk factors in multiple sclerosis. Expert Rev Neurother. 2010;10:421-40.

50. Marrie RA. Environmental risk factors in multiple sclerosis aetiology. Lancet Neurol. 2004;3:709-18.

51. McAlpine D. The problem of disseminated sclerosis. Brain. 1946; 69:233-50.

52. Munger KL, Ascherio A. Risk factors in the development of multiple sclerosis. Expert Rev Clin Immunol. 2007;3:739-48.

53. Poser CM. Physical trauma and multiple sclerosis. Neurology. 1994:44:1360-2.

54. Poser CM. Trauma to the central nervous system may result in formation or enlargement of multiple sclerosis plaques. Arch Neurol. 2000;57:1074-6.

55. Weatherby SJM, Hawkins CP. Does trauma trigger multiple sclerosis? 1: A controversy. Hosp Med. 2003;64:581-4.

56. Weilbach FX, Hartung HP. Physical trauma and multiple sclerosis. Physikalisches trauma und multiple sklerose. Der Nervenartz. 1997;68:940-4.

57. Baker RS. Internuclear ophthalmoplegia following head injury. Case report. J Neurosurg. 1979;51:552-5.

58. Beck RW, Meckler RJ. Internuclear ophthalmoplegia after head trauma. Ann Ophthalmol. 1981;13:671-5.

59. Cerovski B, Vidovic T, Papa J, Cerovski J, Bojic L. Minor head trauma and isolated unilateral internuclear ophthalmoplegia. J Emerg Med. 2006;31:165-7.

60. Chen H, Richard M, Sandler DP, Umbach DM, Kamel F. Head injury and amyotrophic lateral sclerosis. Am J Epidemiol. 2007; 166:810-6.

61. Gallagher JP, Sanders M. Trauma and amyotrophic lateral sclerosis: a report of 78 patients. Acta Neurol Scand. 1987;75:145-50.

62. Gallagher JP, Talbert OR. Motor neuron syndrome after electric shock. Acta Neurol Scand. 1991;83:79-82.

63. Zander E, de Crousaz G. Remarks on the relationship: craniocerebral injuries--multiple sclerosis. Rev Otoneuroophtalmol. 1969;41:391-5

64. Connolly RC. Delayed spinal cord lesions following injury. Riv Patol Nerv Ment. 1965;86:225-9.

65. Constantoyannis C, Tzortzidis F, Papadakis N. Internuclear ophthalmoplegia following minor head injury: a case report. $\mathrm{Br}$ J Neurosurg. 1998;12:377-9.

66. De Portugal Alvarez J, Fereres JS. Considerations on the relationship of injury and multiple sclerosis. Med Clin. 1965;44: 252-5. 
67. Keschner M. The effect of injuries and illness on the course of multiple sclerosis. Res Pub Assoc Res Nerv Ment Dis. 1950;28: 533-47.

68. Miller H. Trauma and multiple sclerosis. Lancet. 1964;283:848-50.

69. Nakamura T, Ota K, Niwa N, Takeuchi M, Uchiyama S, Iwata M. Multiple cerebral white matter lesions following head trauma with eyeball contusion. Clin Neurol. 2004;44:108-10.

70. Namerow NS. A discussion concerning physical trauma in multiple sclerosis. Bull Los Angeles Neurol Soc. 1967;32:117-24.

71. Poser CM. Trauma and multiple sclerosis. An hypothesis. J Neurol. 1987; $234: 155-9$.

72. Bansil S, Singhal BS, Ahuja GK, et al. Multiple sclerosis in India: a case-control study of environmental exposures. Acta Neurol Scand. 1997;95:90-5.

73. Coo H, Aronson KJ. A systematic review of several potential nongenetic risk factors for multiple sclerosis. Neuroepidemiology. 2004;23:1-12.

74. Da Silva KRP, Alvarenga RMP, Fernandez OF, Alvarenga H, Thuler LCS. Potential risk factors for multiple sclerosis in Rio de Janeiro: a case-control study. Arq Neuropsiquiatr. 2009;67: 229-34

75. Dokuchaeva NN, Boiko AN. Clinical and epidemiological study of multiple sclerosis in Volgograd City. Zh Nevrol Psikhiatr Im SS Korsakova. 2006;3:4-10.

76. Gusev EI, Boiko A, Smirnova NF, Demina TL. Risk factors for development of multiple sclerosis in Moscow population. Zh Nevropatol Psikhiatr im SS Korsakova. 1999;99:32-40.

77. Inskip PD, Mellemkjaer L, Gridley G, et al. Incidence of intracranial tumors following hospitalization for head injuries (Denmark). Cancer Causes Control. 1998;9:109-16.

78. Jones F, Fletcher BC. Occupational factors in multiple sclerosis: an analysis of occupational mortality statistics for men and married women in Great Britain. Neuroepidemiology. 1996;15:222-8.

79. Kahana E, Zilber N, Abramson JH, Biton V, Leibowitz Y, Abramsky O. Multiple sclerosis: genetic versus environmental aetiology: epidemiology in Israel updated. J Neurol. 1994;241: 341-6.

80. Koch-Henriksen N. The Danish Multiple Sclerosis Registry: a 50year follow-up. Mult Scler. 1999;5:293-6.

81. Li J, Johansen C, Bronnum-Hansen H, Stenager E, Koch-Henriksen $\mathrm{N}$, Olsen J. The risk of multiple sclerosis in bereaved parents: a nation-wide cohort study in Denmark. Neurol. 2004;62:726-9.

82. Ristori G, Cannoni S, Stazi MA, et al. Multiple sclerosis in twins from continental Italy and Sardinia: a nationwide study. Ann Neurol. 2006;59:27-34

83. Westlund KB, Kurland LT. Studies on multiple sclerosis in Winnipeg, Manitoba, and New Orleans, Louisiana: I. Prevalence. Comparison between the patient groups in Winnipeg and New Orleans. Am J Epidemiol. 1953;57:380-96.

84. Zilber N, Kahana E. Risk factors for multiple sclerosis: a casecontrol study in Israel. Acta Neurol Scand. 1996;94:395-403.
85. Hollander E. Trauma, multiple sclerosis, delayed sleep phase disorder, subjective experiences, and duration of illness in GAD. CNS Spectrums. 2008;13:361-2.

86. Visintainer PF, Lauer K, Poser CM, et al. Physical trauma and multiple sclerosis [1]. Neurology. 1994;44:1360-4.

87. Cohen JR, Katz ER. Playing it safe: prevent falls, cuts, or burns. Momentum. 2008;1:8-9.

88. Gross-Paju K, Oopik M, Luus SM, Kalbe I, Kaasik AE. The risk of motor neurone disease and multiple sclerosis is different in Estonians and Russians. Data from South Estonia. Eur J Neurol. 1999;6:187-93

89. Sibley WA, Bamford CR, Clark K, Smith MS, Laguna JF. A prospective study of physical trauma and multiple sclerosis. J Neurol Neurosurg Psychiatry. 1991;54:584-9.

90. Axelson O, Landtblom AM, Flodin U. Multiple sclerosis and ionizing radiation. Neuroepidemiology. 2001;20:175-8.

91. Landtblom AM, Flodin U, Karlsson M, Palhagen W, Axelson O, Soderfeldt B. Multiple sclerosis and exposure to solvents, ionizing radiation and animals. Scand J Work Environ Health. 1993;19:399-404.

92. Song F, Parekh S, Hooper L, et al. Dissemination and publication of research findings: an updated review of related biases. Health Technol Assess. 2010;14(8):1-220.

93. Lilienfeld AM, Lilienfeld DE. Foundations of epidemiology, 2nd ed. Oxford, UK: Oxford University Press; 1980.

94. Ioannidis JPA. Why most published research findings are false. PLoS Medicine. 2005;2(8):e124.

95. Onyskiw J. The meta-analytic approach to research integration. In: Warren S, Janzen W, Dobbs B, editors. Power in research. Edmonton: RRC Press; 2002. p. 335-51.

96. Allison RS, Millar JHD. Prevalence and familial incidence of disseminated sclerosis; a report to the Northern Ireland Hospitals Authority on the results of a three-year survey. Belfast: Ulster Med Soc; 1954.

97. McAlpine D, Lumsden CE, Acheson D. Multiple sclerosis, a reappraisal. Edinburgh: Churchill Livingstone; 1972.

98. McDonald WI, Compston A, Edan G, et al. Special report Recommended diagnostic criteria for multiple sclerosis: guidelines from the International Panel on the Diagnosis of Multiple Sclerosis. Ann Neurol. 2001;50:121-7.

99. Millar JH, Allison RS. Familial incidence of disseminated sclerosis in Northern Ireland. Ulster Med J. 1954;23:29-92.

100. Poser CM, Paty DW, Scheinberg L, McDonald WI, Davis FA, Ebers GC, et al. New diagnostic criteria for multiple sclerosis: guidelines for research protocols. Ann Neurol. 1983;13:227-31.

101. Rose AS, Ellison GW, Myers LW, Tourtellotte WW. Criteria for the clinical diagnosis of multiple sclerosis. Neurology. 1976;26: 20-2. 